\title{
Instructional/Developmental Communication: Current Theory, Research, and Future Trends
}

By Jon F. Nussbaum and Gustav Friedrich

The Instructional/Developmental Communication Division of ICA has produced a significant literature investigating communication processes within instructional settings as well as communication change occurring throughout the life span. This article documents the significant theoretical developments and empirical findings by communication scholars that have occurred over the past several decades. In addition, based upon the strengths and weaknesses of theory and research, it sets an agenda for future research within instructional/developmental research.

The International Communication Association's Division 7 was founded in 1972 as the Instructional Communication Division. Its original mission was to encourage and support the development and empirical testing of communication theory relevant to individuals interacting in instructional settings.

During the early to mid-1980s, the Instructional Communication Division expanded its mission and its name to include scholarship in developmental communication. Jan Andersen, Robert Norton, Gus Friedrich, Jon Nussbaum, and numerous others realized that the current research addressing instruction-related issues within the discipline of communication could no longer escape the fact that learning, teaching, and interaction across the wide variety of instructional contexts was at its core a developmental phenomenon. Stated simply, instructional scholars were moving beyond the investigation of the perceptions or behavior of college sophomores that at times included interaction with teachers and other students.

Communication researchers have now produced an impressive literature investigating interaction in various contexts across the entire life span. Instructional researchers have investigated $\mathrm{K}-12$ classrooms, learning environments that attract nontraditional students, and instructional settings far removed from our notion of the average classroom, such as continuous learning in organizations or advanced

Jon F. Nussbaum (PhD, Purdue University) is a professor in the Department of Communication Arts and Sciences at The Pennsylvania State University. Gustav Friedrich (PhD, University of Kansas) is dean of the School of Communication, Information, and Library Studies at Rutgers University.

Copyright (C) 2005 International Communication Association 
training settings. At the same time, a new cadre of scholars began publishing manuscripts studying the communicative behavior of individuals who were much younger or much older than the typical college student. Theories have been developed and tested that specifically outline the significance of the interactants' age and experience within any communication exchange.

This article documents the communication perspectives and theories that are having a significant impact upon scholars within instructional/developmental communication. The knowledge that has been acquired through the empirical investigations by instructional/developmental scholars within the discipline of communication will be presented and discussed. In addition, we will offer suggestions for future research into instructional/developmental communication based upon the strengths and weaknesses of current theory and research.

\section{Instructional Communication}

Almost from the establishment of academic departments in the United States, teachers of communication have devoted intellectual effort to understanding and improving communication in instructional settings. Smith (1954) reported that speech courses for teachers were offered at Indiana University in 1892; by the 1910-1920 decade, such courses were widely available. Much of these early efforts involved applying communication theory and research generated in noninstructional contexts to the interactions of teachers and students in instructional settings. It has been largely within the context of Division 7 that researchers have focused on developing instructional communication theory based on systematic programs of empirical research conducted in instructional contexts.

There have been several efforts to summarize the status of instructional communication research since the beginning of Division 7 , starting with chapters in the first five volumes of ICA's Communication Yearbook. A more systematic effort to summarize such work was reported by Staton-Spicer and Wulff (1984). In this essay, they identified, categorized, and synthesized 186 empirical studies of communication and instruction reported in ICA, NCA, and regional communication journals for the years 1974 through 1981.

Most recently, Waldeck, Kearney, and Plax (2001) reviewed and interpreted instructional and developmental communication theory and research in the 1990s in an essay published in Communication Yearbook 24. Their analysis focused on 186 Division 7-relevant empirical research studies published between 1990 and winter 1999 in journals indexed by the NCA's Index of Journals in Communication Studies.

The lion's share of these studies were published in Communication Education (88 of the 186). Coming in second and third were Communication Research Reports (31) and Communication Quarterly (22). Twelve additional journals were in single digits (less than 10), and eight published no relevant studies.

Waldeck et al. (2001) identified 12 major theories associated with the 186 studies (arousal theory, Keller's ARCS model of instructional design, French \& Raven's bases of power, attribution theory, expectancy learning/learned helplessness, arousal 
valence theory, approach/avoidance theory, information-processing theory, social learning/cognitive theory, cultivation theory, and developmental theories). The important point here is that instructional communication scholars are grounding their research in theory. It is worth noting, however, that all of these theories, with the single exception of Gerbner's cultivation theory (a theory that explains the process by which heavy television viewing influences people's perception of reality), are imported from other social science disciplines. In addition, none of these theories were developed by instructional communication researchers.

Waldeck et al. (2001) also created a six-category coding scheme for summarizing the foci of these studies. Because some studies have more than one focus, the 186 studies resulted in the 271 cases reported in Table 1 . As you will discover by exploring it, the 186 studies feature 46 topics. Only 7 of these topics, though, are the focus of 10 or more studies: student communication apprehension/public speaking anxiety (53 studies), teacher immediacy-related behaviors (28), student culture/gender (26), student motivation/demotivation (14), TV effects on children (14), technology as a pedagogical aid (12), and teacher credibility (12). In addition, 14 of the topics are featured in only one study.

So what can we conclude about the current status of instructional communication research? Waldeck et al. (2001) made four suggestions in terms of future research efforts: First, after observing that much of current research has focused independently on teacher behaviors (e.g., teacher affinity-seeking) and student behaviors (e.g., communication competence), they suggested that more investigations should explore how teachers' and students' interactions influence learning (e.g., teacher clarity strategies interacting with student clarifying strategies); second, they suggested that instructional communication researchers devote more effort to exploring student-to-student interactions; third, they recommended greater focus on the role of technology in instruction both in the classroom and in distance education; finally, they suggested that researchers do a better job of highlighting and explicating the theoretical bases or implications of their research.

These suggestions of Waldeck et al. (2001) can be supplemented by two additional observations: First, the vast majority of instructional communication research has been conducted in college classrooms, a significant exception being the research on mass media effects in children. This is in contrast to the work of educational psychologists, who more frequently, and often with significant governmental and private grant support, focus on earlier educational levels. Given the rationale for adding a developmental emphasis to Division 7 , it is only logical to recommend that instructional research become more balanced along the developmental continuum. Such a move has the potential of producing greater external support for our research. Second, the vast majority of instructional research has been conducted within the context of one of the three dominant philosophical traditions for social science research (Soltis, 1984), logical empiricism (positivism) - a tradition that assumes that the role of the researcher is to construct and empirically test general laws or principles that allow one to explain, predict, and control the reality being studied. Although there has been a small amount of significant work in the interpretative tradition (analytical, phenomenological, and hermeneutic), largely by Ann Staton (1990) and her students, there has been little 


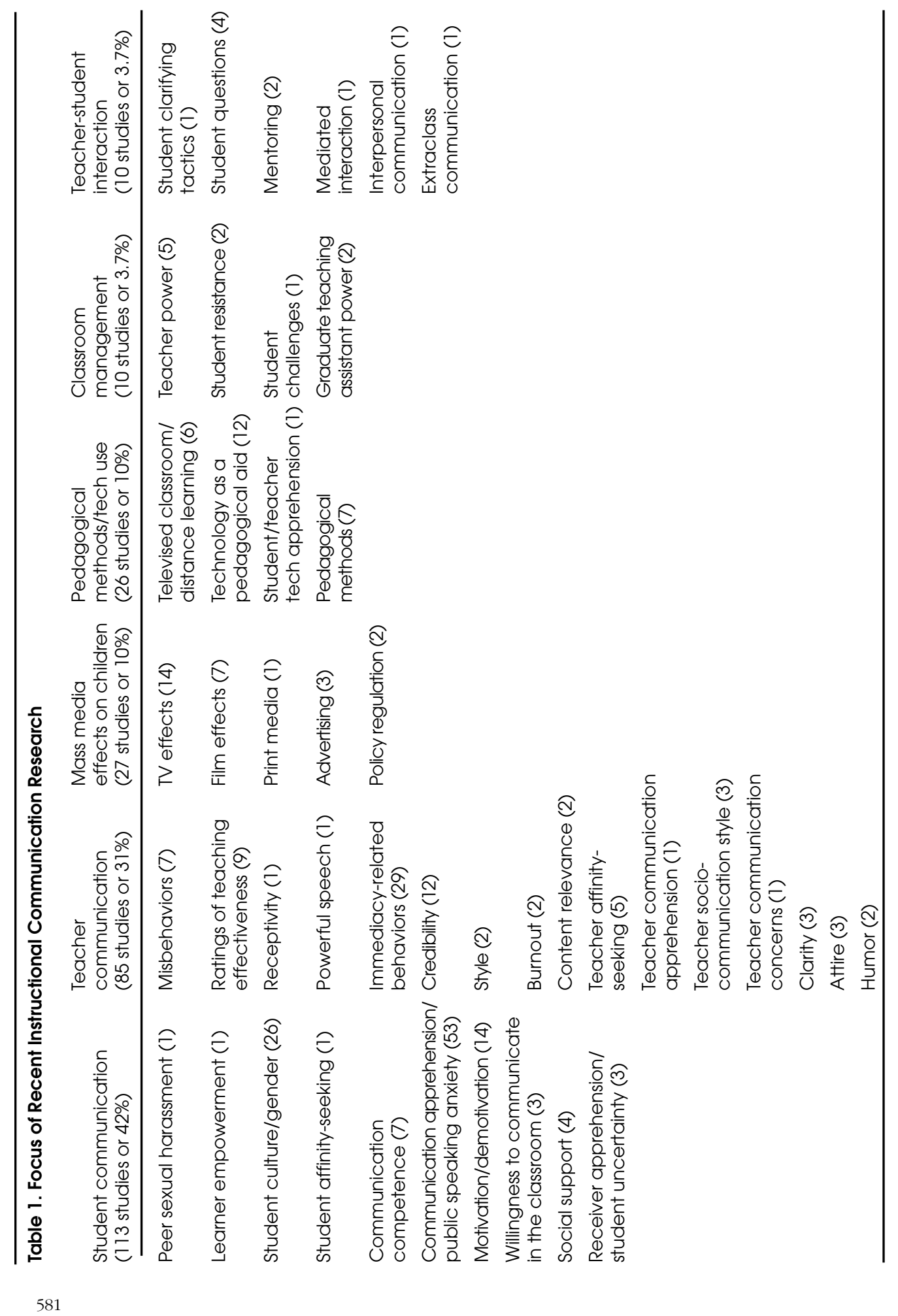


work produced from within the critical theory perspective (neo-Marist; feminist), a perspective that Jo Sprague (1992a, 1992b, 1993, 1994) has eloquently championed. Once again, this is in sharp contrast to the work of educational psychologists, whose research within both the interpretive tradition and critical theory perspective is common.

Waldeck and colleagues concluded their review of the instructional communication literature by describing (and lamenting) their general conclusion that despite the prolific nature and high quality of the instructional communication research they had just summarized, this output had produced few large-scale knowledge claims and had received little attention from educators outside the communication discipline. They attributed this state of affairs to multiple complex reasons, including (a) failure to acknowledge the critical distinction between communication education and instructional communication; (b) a focus on variable-analytic research strategies that make theory building difficult; and (c) confusion resulting from conceptual and operational overlap among related constructs.

Whereas the second two are worthy additions to the instructional communication research agenda, the first point suggested by Waldeck and colleagues is worth additional examination. Their point was that many individuals in the communication discipline see instructional communication (the role of communication in teaching and learning) and communication education (facilitating the development of communication competencies) as synonymous. The former, they believe, was more theory- and research-based than is the later, leaving instructional communication tainted by association with communication education. As evidence for this confusion, they pointed to the fact that much instructional communication research is published in Communication Education with little of it published in more mainstream journals like Human Communication Research, Journal of Communication, Journal of Applied Communication, or Communication Monographs. Their proposed solution was to rename the journal Instructional Communication and require that all research reports published in it include a section on theoretical implications. Although we are not disagreeing with their identification of a problem, it is not clear that the proposed strategy will solve it. Solving the problem this way continues a strategy of relegating both instructional communication and communication education to the ghetto of one journal. Only when the best research in both domains is perceived as strong enough to be published in the mainstream journals of the discipline will it have the respect that it deserves, both within the discipline and outside it.

We should also note that, given our earlier analysis of how the instructional communication literature might be improved, it is worthwhile to reconsider the label "instructional communication." This term focuses on one part of the equation (the instructor or teacher) and fails to capture either students or the interactive nature of communication within the context of teaching and learning. Might not a better term be something like "educational communication"? Also, instead of considering instructional communication and communication education as two separate and competing domains of research, it is more productive to see both as operating within the broader picture of systems of teaching and learning. One way of doing this is described by Friedrich (2002) using Lee S. Shulman's (1987) 
model of "knowledge growth in teaching" to suggest a research agenda for communication education. Shulman's model focused on seven categories of the knowledge base required by competent teachers:

Content knowledge, the knowledge base that defines the discipline;

General pedagogical knowledge, those broad principles and general strategies of classroom management and organization that appear to transcend subject matter;

Curriculum knowledge, the materials and programs that appear to transcend subject matter;

Pedagogical content knowledge, that special amalgam of content and pedagogy that is uniquely the province of teachers, their own special form of professional understanding;

Knowledge of learners and their characteristics;

Knowledge of educational contexts, ranging from the workings of the group or classroom, the governance and financing of school districts, to the character of communities and cultures; and

Knowledge of educational ends, purposes, and values, and their philosophical and historical grounds.

Within Shulman's analysis, instructional communication (general pedagogical knowledge applicable to all teachers) and communication education (content knowledge, curriculum knowledge, and pedagogical content knowledge) are complementary rather than competing domains. Both are required for communication teaching and learning to be effective.

In summary, then, largely in conjunction with the development of ICA's Division 7 , researchers have developed rigorous programs of research focused on developing communication theory relevant to individuals interacting in instructional settings. An exemplar of this type of research is that of James C. McCroskey and Virginia P. Richmond and their colleagues and students on power in the classroom. There are multiple additional excellent programs of instructional communication research, including teacher immediacy (building on the work of Janis Andersen), student and teacher socialization (Ann Staton and her students and colleagues), instructional behaviors (Jon Nussbaum and others), and teacher and student feedback (Jo Sprague and others).

There is always room for improvement, though, and improvement can result, we suggest, from an increased focus on theory construction and testing, teacherstudent interactions, student-to-student interactions, the role of technology in instruction, grant support for research, underresearched settings and educational levels, interpretive and critical research traditions, and exploration of conceptual and operational overlap, among related constructs. In addition, we suggest that both communication education research and instructional communication research are necessary and complementary contributions to understanding the role of communication in educational settings. 


\section{Developmental Communication}

The communication discipline has followed its sister disciplines of psychology and sociology in an attempt to describe and understand the communication process across the entirety of the life span. Whereas life-span developmental psychology, for instance, became mainstream in the late 1960s and early 1970s (e.g., Goulet \& Baltes, 1970; Neugarten, 1968), the study of developmental communication within the discipline of communication emerged during the late 1970s and 1980s. Carl Carmichael and Robert Hawkins organized an action caucus on communication and aging at the annual conference of the National Communication Association in 1979. This led to a summer conference in 1981 that ultimately produced a book entitled Human Communication and the Aging Process (Carmichael, Botan, \& Hawkins, 1988). A few years later, in the summer of 1988, a Fulbright International Colloquium was organized by Nikolas Coupland, Howard Giles, and John Wiemann in mid-Wales entitled Communication, Health, and the Elderly. At the same time, numerous books such as Communication and Aging (Nussbaum, Thompson, \& Robinson, 1989), Life-span Communication: Normative Processes (Nussbaum, 1989), and Language, Society and the Elderly (Coupland, Coupland, \& Giles, 1991) were synthesizing the growing number of studies related to communication and the aging process. It should be noted that this first surge in developmental communication research theory and research targeted older adults. A second group of developmental communication scholars have targeted children and the possible effects the media have upon their lives. Their work will be discussed later.

\section{Life Span Communication}

Knapp (1978), Nussbaum (1981), and others began speculating over 2 decades ago that a life span approach may be a useful metaperspective in our attempt to better understand and explain communication behavior. "The basic premise of any lifespan developmental approach that investigates human behavior is that potential for development extends throughout the lifespan" (Nussbaum, Pecchioni, Baringer, \& Kundrat, 2002, p. 368). Five assertions of the life span perspective have been advanced by Baltes (1987) and help to clarify the significance of this perspective for all social scientists. First, the life span perspective rejects commonly accepted notions of almost universal decline as we age. Second, development in various behaviors may occur at different times with different speed. Third, development is best viewed as a gain-loss dynamic. Fourth, there is much intraand interindividual diversity throughout the life span. Finally, one must consider the powerful effects of the environment upon the development of human behavior.

This life span perspective originally outlined by Baltes (1987) has been adopted and modified by communication scholars (Nussbaum, 1989; Nussbaum et al., 2000; Williams \& Nussbaum, 2001) and has produced a line of research that investigates the changing nature and function of a variety of relationships. Studies have been conducted that compare the very nature of friendship at various times in our lives (Patterson, Bettini, \& Nussbaum, 1993), the importance of sibling relationships as we age (Cicirelli \& Nussbaum, 1989), the older parent-adult child relationship 
(Bethea, 2002; Cicirelli, 1981; Fingerman, 2001; Morgan \& Hummert, 2000; Pecchioni \& Nussbaum, 2000), the grandparent-grandchild relationship (Harwood \& Lin, 2000; McKay \& Caverly, 1995; Nussbaum \& Bettini, 1994), and the relationship older adults have with their often younger physician or caregiver (Williams \& Nussbaum 2001). In addition, the communication behavior of older individuals living within long-term care facilities has been studied (Nussbaum, Bergstrom, \& Sparks, 1996; Nussbaum, Robinson, \& Grew, 1985). These investigations have shown that our communicative behavior does indeed change across the life span. This communicative change is dynamic and complex and often functions to aid in the successful adaptation to the aging process. Indeed, numerous communicative changes serve to aid our ability to maintain effective relationships across time and distance that ultimately make life much more livable.

This line of research has also helped to confirm many of the original assertions spelled out by Baltes (1987). The communication behavior occurring within the relationships discussed above has not been found to universally decline as we age. Certain communicative behaviors and relationships serve us well at different points across the life span. The great diversity in the nature of relationship development and in the adaptability of our communicative behavior within numerous, simultaneously occurring relationships emerges from these investigations. Finally, and perhaps most importantly, these investigations have focused attention on the many environmental factors such as relationship experience, history, significant life events, parenthood, grandparenthood, work relationships, friendship networks, life crises, and health-related issues, just to name a few, that can significantly impact our communicative behavior.

\section{Communication Accommodation Theory}

Howard Giles and his many colleagues have advanced communication accommodation theory (CAT; Giles, Coupland, \& Coupland, 1991) describing "the social cognitive processes mediating individuals' perceptions of the environment and their communicative behaviors" (Giles, Mulac, Bradac, \& Johnson, 1987, p. 14). CAT has been a valuable tool that helps communication scholars describe and explain the way individuals modify their speech according to situational, personal, or even interactional variables. Excellent reviews of CAT exist in the literature (see Gallois, Giles, Jones, Cargile, \& Ota, 1995; Giles et al., 1991). Stated simply, when two interactants are conversing, each person adapts certain strategies during the conversation. The individual may choose not to modify his or her style of communication, may choose to modify his or her style to converge toward the conversational partner, or may choose to diverge from the perceived style of the other interactant. As an individual modifies his or her communicative behavior within an interaction, he or she is likely to underaccommodate or overaccommodate. "Underaccommodation is when some style or quantity of talk is underplayed relative to the needs or wishes of an interlocutor" (Williams \& Nussbaum, 2001, p. 86). "Overaccommodation may be defined as the overplaying of a particular language or communication style relative to the needs, wishes, or desires of the listener" (p. 108). CAT has played a significant role as the major theory utilized to describe and explain intergenerational communication (Williams \& Nussbaum, 2001). 
The study of intergenerational communication has been a mainstay of developmental communication research for well over a decade. Ryan, Giles, Bartolucci, and Henwood (1986) found that underaccommodation is the predominate perception from young people of older adults' talk. One particular aspect of underaccommodation, painful self-disclosure, has received a good deal of empirical investigation (Coupland, Henwood, Coupland, \& Giles, 1990; Giles, Coupland, \& Wiemann, 1992). A painful self-disclosure occurs when an older adult discloses to a younger person a piece of painful information often concerning bad health, bereavement, or social deprivation. Overaccommodation is considered to be rather typical of young people's communication with older adults. Health care workers have been shown to utilize patronizing communication (Ryan et al., 1986), "elderspeak" (Cohen \& Faulknet, 1986), and "baby talk" (Caporael, 1981) when interacting with older adults. This slow, oversimplified, polite, and overly warm conversational style is considered to be inappropriate at times and has been shown to cause significant difficulties within health care contexts (Williams \& Nussbaum, 2001).

Harwood (2000) has recently applied CAT to the realm of personal relationships. In his study of the grandparent-grandchild relationship, communication variables performed considerably better than demographic variables in predicting communication satisfaction, liking, and emotional closeness. "For both grandparents and grandchildren, the most consistent predictor of relational solidarity was the perceptions of their partners' level of accommodation to them" (Harwood, 2000, p. 759). Harwood has provided evidence that CAT can be a useful theoretical perspective with which to study communicative behavior within intergenerational family and friendship relationships.

\section{Communication Predicament and Enhancement Models of Aging}

Based solidly within the CAT perspective, Ryan et al. (1986) advanced the communication predicament model of aging to explain how stereotypes directed toward older adults and the aging process may lead to problematic speech that ultimately affects the health care of older adults. The model predicts that any individual who encounters an older adult will be initially influenced by old age cues such as gray hair, wrinkled skin, and slow movement. These cues will make negative age stereotypes salient, causing modifications in speech behavior toward the older adult. This overaccommodation in communication style can then lead to a reinforcement of negative age-stereotyped behavior, constrained opportunities for communication, loss of self-esteem on the part of the older adult, lessened psychological activity and social interaction, and a change in behavior by the older adult that are consistent with the negative stereotypes.

Empirical findings have supported many of the predictions of the communication predicament model. Older speakers have been evaluated more negatively than younger speakers on numerous personality and attitude scales (Giles, Henwood, Coupland, Harriman, \& Coupland, 1992; Ryan \& Capandano, 1978; Ryan \& Johnston, 1987, Stewart \& Ryan, 1982). Younger facial features have been associated with more positive traits than older facial features (Berry \& McArthur, 1986). Giles et al. (1992) have demonstrated that perceptions of communication 
competence decline with advancing age. Ryan, Kwong, Meneer, and Trovato (1992) pointed out that beliefs about the communication behavior of older adults can lead to the patronizing talk or the overaccommodations described above. A series of studies (see Hummert, Garstka, Ryan, \& Bonnesen, 2004, for an excellent review) have demonstrated that these overaccommodations directed toward older adults can lead to the negative consequences predicted by the model.

The negative consequences resulting from stereotyping and overaccommodations are primarily based upon stranger, intergenerational interactions occurring in healthrelated environments. Ryan, Meredith, Maclean, and Orange (1995) created the communication enhancement model to indicate that the negative loop of stereotypes and behavior can be avoided. A positive cycle of interaction with an older adult can be achieved through an individualized, person-centered approach. The negative stereotypes based upon a general categorization need to be replaced by a constant individualized assessment of the interaction as it progresses. "If the partners engage in appropriate adaptations, the enhancement model sees positive outcomes for both parties in terms of empowerment, increased competence, satisfaction, health, and effective communication" (Hummert et al., 2004, p. 108).

\section{The Age Stereotypes in Interactions Model}

Hummert (1994) proposed the age stereotypes in interaction model (ASI) to stress the role of both positive and negative stereotypes of older adults and the effects these stereotypes have upon communication behavior. "The ASI model posits that three aspects of the perceiver's self-system are centrally involved in the stereotyping process: age, cognitive complexity, and quality of prior contact" (Hummert et al., 2004, p. 100). The older adult's physical features and communication behaviors suggesting either positive or negative age stereotypes will influence the stereotyping process. In addition, the context of the communicative encounter may favor either a negative or a positive age stereotype. The three major components of the model (the perceiver's self-system, characteristics of the older adult, and the context of the interaction) influence the stereotyping process that ultimately may lead to either positive or negative interactive consequences.

Hummert et al. (2004), in their excellent review of the role of age stereotypes in communication, cited numerous studies that provide support for the ASI model. Investigations by Bonnesen and Hummert (2002), Bieman-Copland and Ryan (2001), Mulac and Giles (1996), Harwood and Williams (1996), Hummert, Garstka, and Shaner (1997), Ryan, Kennaley, Pratt, and Shumovich (2000), Thimm, Rademacher, and Kruse (1998), and others have shown that both positive and negative stereotypes are activated by an encounter with an older target. This activation then leads to stereotypic beliefs about the older adult's communicative competencies that are consistent with the stereotype's valence. In addition, the communicative behavior of the older adult can dramatically influence whether the negative stereotypes are reinforced or whether the negative stereotypes are replaced by a much more positive belief about the older target. The findings are important because they reinforce the notion that the communication process is dynamic and that our interpersonal interactions with older adults do not have to be determined by societal, often negative, stereotypes of old age. 
Children and the Media

Developmental communication researchers have also focused their attention upon the use and effects of media on children. Joanne Cantor, Barbara Wilson, Cynthia Hoffner, and numerous others have systematically investigated children's responses to frightening mass media presentations (Cantor \& Wilson, 1984; Hoffner, 1997; Hoffner \& Cantor, 1990; Wilson, 1987, Wilson \& Cantor, 1985; Wilson, Hoffner, \& Cantor, 1987). These fear reactions are quite common among children and often endure beyond the viewing situation causing emotional disturbances. This research has attempted to explain these fear reactions and to devise effective coping methods for children. Hoffner (1997) reported some support for the activationarousal framework for mass media use and effects proposed by Sparks and Spirek (1988).

Another extensive line of research conducted by developmental communication scholars centers around the impact of TV violence on children. The March 2002 issue of the Journal of Communication, edited by Barbara Wilson, was dedicated to the empirical findings that were part of a large grant supported by the National Cable Television Association. Results from these investigations indicated that violence varies greatly across different programming categories; that children perpetrators of violence are more often portrayed as attractive, are less likely to be punished, and engage in violence that results in fewer negative consequences to other victims than adult perpetrators; and that viewers are likely to encounter violence in two out of three programs regardless of the time of viewing.

Other research topics investigated by developmental communication scholars have included the effect of a child's age on his or her interpretation of an act of interpersonal violence on television (Krcmar \& Cooke, 2001), the program characteristics children value on television (Valkenburg \& Janssen, 1999), children's cognitive and emotional responses to negative emotions in family-formatted situation comedies (Weiss \& Wilson, 1998), family communication patterns and parentchild discourse (Krcmar, 1996), effects of talk show viewing on adolescents (Davis \& Mares, 1998), and the effects of extensive experience on children's television viewing (Crawley et al., 2002), to name a few.

\section{Future Research Agendas in Developmental Communication Research}

In stark contrast to research within instructional communication, developmental communication research has been solidly grounded in theories developed by communication scholars. These theories are in a continuous process of testing and revision thanks mainly to the efforts of Howard Giles, Ellen Ryan, Mary Lee Hummert, Jake Harwood, Angie Williams, Jon Nussbaum, Loretta Pecchioni, Lisa Sparks, Mark Bergstrom, and others. For instance, Giles and his colleagues have recently responded to a call for models and theories to include the possible significant effects of intragenerational concerns by positing a integrative model of inter- and intragenerational communication (Barker, Giles, \& Harwood, 2004). "This new model incorporates the notion that communication proceeds at, and is influenced by, multiple levels of social interaction" (Barker et al., p. 150). 
Intrapersonal, interpersonal, intergroup, and cultural differences are all incorporated into a prediction of possible communicative outcomes within a communicative encounter. The great strength of developmental communication is the theoretical advances being made by communication scholars. There is every reason to believe that these advances will continue far into the future.

Two specific areas of research are ripe for future investigation by developmental communication scholars. First, all life stages have not been equally addressed. Most notably absent from intensive investigation are adolescents and mid-life individuals. As noted in the review of empirical findings cited above, the great majority of scholarship has been devoted to children and to older adults. This is true across all of the social sciences. Communication scholars need to focus their attention on the very dynamic and ever-changing world of the adolescent. From peer interaction to multigenerational family interaction, our understanding of the dayto-day communication experiences of adolescents and any impact these actions have upon their current or future lives is an unknown. The same can be said for the large segment of our lives "lived" between the ages of 45 and 60. Fingerman, Nussbaum, and Birditt (2004) recently discussed mid-life as perhaps the most challenging communicative time of our lives as we attempt to juggle multiple intergenerational relationships simultaneously. Yet, very little is known about how to accomplish these demanding interactive tasks.

The second major area of inquiry into developmental communication concerns the appropriate methodologies with which to capture change. Nussbaum et al. (2002) noted that designing and conducting empirical investigations that capture communicative change across the life span is a rather complex task. "There is a virtual consensus among quantitative social scientists that one of the most productive approaches to the study of aging and human development involves the collection and analysis of longitudinal data" (Alwin \& Campbell, 2001, p. 22). To date, no major, funded communication initiative is ongoing to investigate communication across the life span utilizing longitudinal methods. In addition, statistical tools such as structural equation modeling have been shown to work well within investigations that attempt to document significant changes across time. Longitudinal methodologies and sophisticated statistical tools, although rather common in life-span developmental psychology, are rare, as evidenced by not only few publications utilizing such methodologies, but by the lack of such courses being required within our doctoral granting departments. Communication scholars will need to become much better acquainted with these sophisticated methodologies if developmental communication is to add significantly to the general knowledge base within life span studies.

\section{References}

Alwin, D. F., \& Campbell, R. T. (2001). Quantitative approaches: Longitudinal methods in the study of human development and aging. In R. H. Binstock \& L. K. George (Eds.), Handbook of aging in the social sciences (pp. 22-43). San Diego, CA: Academic Press.

Baker, V., Giles, H., \& Harwood, J. (2004). Inter- and intragroup perspectives on intergenerational communication. In J. F. Nussbaum \& J. Coupland (Eds.), Handbook of communication and aging research (2nd ed.; pp. 139-166). Mahwah, NJ: Erlbaum. 
Baltes, P. B. (1987). Theoretical propositions of life-span developmental psychology: On the dynamics between growth and decline. Developmental Psychology, 23, 611-626.

Berry, D. S., \& McArthur, L. A. (1986). Perceiving character in faces: The impact of age-related craniofacial changes on social perception. Psychological Bulletin, 100, 3-18.

Bethea, L. S. (2002). The impact of an adult parent on communicative satisfaction and dyadic adjustment in the long-term marital relationship: Adult-children and spouses' retrospective accounts. Journal of Applied Communication Research, 30, 107-125.

Bieman-Copland, S., \& Ryan, E. B. (2001). Social perceptions of failures in memory monitoring. Psychology and Aging, 16, 357-361.

Bonnesen, J. L., \& Hummert, M. L. (2002). Painful self disclosures of older adults in relation to aging stereotypes and perceived motivations. Journal of Language and Social Psychology, 21, 275-301.

Cantor, J., \& Wilson, B. J. (1984). Modifying fear responses to mass media in preschool and elementary school children. Journal of Broadcasting, 28, 431-443.

Caporael, L. R. (1981). The paralanguage of caregiving: Baby talk to the institutionalized aged. Journal of Personality and Social Psychology, 40, 876-884.

Carmichael, C. W., Botan, C. H., \& Hawkins, R. (1988). Human communication and the aging process. Prospect Heights, IL: Waveland Press.

Cicirelli, V. G. (1981). Helping elderly parents: The role of adult children. Boston: Auburn House.

Cicirelli, V. G., \& Nussbaum, J. F. (1989). Relationships with siblings in later life. In J. F. Nussbaum (Ed.), Life-span communication: Normative processes (pp. 283-297). Hillsdale, NJ: Erlbaum.

Cohen, G., \& Faulkner, D. (1986). Memory for proper names: Age differences in retrieval. British Journal of Developmental Psychology, 4, 187-197.

Coupland, N., Coupland, J., \& Giles, H. (1991). Language, society $\&$ the elderly. Oxford, UK: Blackwell.

Coupland, N., Henwood, K., Coupland, J., \& Giles, H. (1990). Accommodating troubles-talk: The young's management of elderly self-disclosure. In G. M. McGregor \& R. White (Eds.), Reception and response, Hearer creativity and the analysis of spoken and written texts (pp. 112-133). London: Croom-Helm.

Crawley, A. M., Anderson, D. R., Santomero, A., Wilder, A., Williams, M., Evans, M. K., \& Bryant, J. (2002). Do children learn how to watch television? The impact of extensive experience with Blues Clues on preschool children's television viewing behavior. Journal of Communication, $52,264-280$.

Davis, S., \& Mares, M-L. (1998). Effects of talk show viewing on adolescents. Journal of Communication, 48(3), 69-86.

Fingerman, K. L. (2001). Aging mothers and their adult daughters: A study in mixed emotions. New York: Springer.

Fingerman, K. L., Nussbaum, J. F., \& Birditt, K. S. (2004). Keeping all five balls in the air: Juggling family communication at midlife. In A. L. Vangelisti (Ed.), Handbook of family communication (pp. 135-152). Mahwah, NJ: Erlbaum.

Friedrich, G. W. (2002). The communication education research agenda. Communication Education, $51,372-375$.

Gallois, C., Giles, H., Jones, E., Cargile, A. C., \& Ota, H. (1995). Accommodating intercultural encounters: Elaborations and extensions. In R. L. Wiseman (Ed.), Intercultural communication theory (pp. 115-147). Thousand Oaks, CA: Sage.

Giles, H., Coupland, J., \& Coupland, N. (1991). Contexts of accommodation: Developments in applied linguistics. Cambridge, UK: Cambridge University Press.

Giles, H., Coupland, J., \& Wiemann, J. M. (1992). "Talk is cheap" but "my word is my bond": Beliefs about talk. In K. Bolton \& H. Kwock (Eds.), Sociolinguistics today: Eastern and western perspectives (pp. 218-243). London: Routledge. 
Giles, H., Henwood, K., Coupland, N., Harriman, J., \& Coupland, J. (1992). Language, attitudes, and cognitive mediation. Human Communication Research, 18, 500-527.

Giles, H., Mulac, A., Bradac, J. J., \& Johnson, P. (1987). Speech accommodation theory: The last decade and beyond. In M. L. McLaughlin (Ed.), Communication yearbook 10 (pp. 13-48). Beverly Hills, CA: Sage.

Goulet, L. R., \& Baltes, P. B. (1970). Life-span developmental psychology: Research and theory. New York: Academic Press.

Harwood, J. (2000). Communication predictors of solidarity in the grandparent-grandchild relationship. Journal of Social and Personal Relationships, 17, 28-47.

Harwood, J., \& Lin, M-C. (2000). Affiliation, pride, exchange, and distance in grandparents' accounts of relationships with their college-aged grandchildren. Journal of Communication, 50(3), 31-47.

Harwood, J., \& Williams, A. (1996). Expectations for communication with positive and negative subtypes of older adults. International Journal of Aging and Human Development, 47, 11-33.

Hoffner, C. (1997). Children's emotional reactions to a scary film: The role of prior outcome information and coping style. Human Communication Research, 23, 323-314.

Hoffner, C., \& Cantor, J. (1990). Forewarning of a threat and prior knowledge of outcome: Effects on children's emotional responses to a film sequence. Human Communication Research, 16, 323-354.

Hummert, M. L. (1994). Stereotypes of the elderly and patronizing speech style. In M. L. Hummert, J. H. Wiemann, \& J. F. Nussbaum (Eds.), Interpersonal communication in older adulthood (pp. 162-184). Thousand Oaks, CA: Sage.

Hummert, M. L., Garstka, T. A., Ryan, E. B., \& Bonnesen, J. L. (2004). The role of age stereotypes in interpersonal communication. In J. F. Nussbaum \& J. Coupland (Eds.), Handbook of communication and aging research (2nd ed.; pp. 91-114). Mahwah, NJ: Erlbaum.

Hummert, M. L., Garstka, T. A., \& Shaner, J. L. (1997). Stereotyping of older adults: The role of target facial cues and perceiver characteristics. Psychology and Aging, 12, 107-114.

Hummert, M. L., \& Nussbaum, J. F. (Eds.), Interpersonal communication in older adulthood: Interdisciplinary theory and research (pp. 162-185). Newbury Park, CA: Sage.

Knapp, M. L. (1978). Social intercourse: From greeting to goodbye. Boston: Allyn \& Bacon.

Krcmar, M. (1996). Family communication patterns, discourse behavior, and child television viewing. Human Communication Research, 23, 278-297.

Krcmar, M., \& Cooke, M. C. (2001) Children's moral reasoning and their perceptions of television violence. Journal of Communication, 51, 300-316.

McKay, V. C., \& Caverly, R. S. (1995). Relationships in later life: The nature of inter- and intra-generational ties between grandparents, grandchildren, and adult siblings. In J. F. Nussbaum \& J. Coupland (Eds.), Handbook of communication and aging research (pp. 207-226). Mahwah, NJ: Erlbaum.

Morgan, M., \& Hummert, M. L. (2000). Perceptions of communicative control strategies in motherdaughter dyads across the life span. Journal of Communication, 50(3), 48-64.

Mulac, A., \& Giles, H. (1996). "You're only as old as you sound": Perceived vocal age and social meanings. Health Communication, 8, 199-215.

Neugarten, B. L. (1968). Middle age and aging. Chicago: University of Chicago Press.

Nussbaum, J. F. (1981). Interactional patterns of elderly individuals: Implications for successful adaptation to aging. Unpublished doctoral dissertation, Purdue University, West Lafayette, IN.

Nussbaum, J. F. (1989). Life-span communication: Normative processes. Hillsdale, NJ: Erlbaum.

Nussbaum, J. F., Bergstrom, M., \& Sparks, L. (1996). The institutionalized elderly: Interactive implications of long-term care. In E. B. Ray (Ed.), Communication and disenfranchisement (pp. 219-229). Mahwah, NJ: Erlbaum. 
Nussbaum, J. F., \& Bettini, L. M. (1994). Shared stories of the grandparent-grandchild relationship. International Journal of Aging and Human Development, 39, 67-80.

Nussbaum, J. F., Pecchioni, L. L., Baringer, D. K., \& Kundrat, A. L. (2002). Lifespan communication. In W. B. Gudykunst (Ed.), Communication yearbook 26, 366-389. Mahwah, NJ: Erlbaum.

Nussbaum, J. F., Pecchioni, L., Robinson, J. D., \& Thompson, T. L. (2001). Communication and aging (2nd ed.). Mahwah, NJ: Erlbaum.

Nussbaum, J. F., Robinson, J. D., \& Grew, D. J. (1985). Communication behavior of the long-term health care employee: Implications for the elderly resident. Communication Research Reports, 2, 16-22.

Nussbaum, J. F., Thompson, T., \& Robinson, J. D. (1989). Communication and aging. New York: Harper \& Row.

Patterson, B. R., Bettini, L., \& Nussbaum, J. F. (1993). The meaning of friendship across the lifespan: Two studies. Communication Quarterly, 41, 145-160.

Pecchioni, L. L., \& Nussbaum, J. F. (2000). The influence of autonomy and paternalism on communicative behaviors in mother-daughter relationships prior to dependency. Health Communication, 12, $317-338$.

Ryan, E. B., \& Capadano, H. L. (1978). Age perceptions and evaluative reactions toward adult speakers. Journal of Gerontology, 33, 98-102.

Ryan, E. B., Giles, H., Bartolucci, G., \& Henwood, K. (1986). Psycholinguistic and social psychological components of communication by and with the elderly. Language and Communication, 6, 1-24.

Ryan, E. B., \& Johnston, D. G. (1987). The influence of communication effectiveness on evaluations of younger and older speakers. Journal of Gerontology, 42, 163-164.

Ryan, E. B., Kennaley, D. E., Pratt, M. W., \& Shumovich, M. A. (2000). Evaluations by staff, residents, and community seniors of patronizing speech in nursing homes: Impact of passive, assertive or humorous responses. Psychology and Aging, 15, 272-285.

Ryan, E. B., Kwong See, S., Meneer, W. B., \& Trovato, D. (1992). Age based perceptions of language performance among young and older adults. Communication Research, 19, 423-443.

Ryan, E. B., Meredith, S. D., MacLean, M. J., \& Orange, J. B. (1995). Changing the way we talk with elders: Promoting health using the dommunication enhancement model. International Journal of Aging and Human Development, 41, 87-105.

Shulman, L. S. (1986). Those who understand: Knowledge growth in teaching. Educational Research, 15, 4-14.

Shulman, L. S. (1987). Knowledge and teaching: Foundations of the new reform. Harvard Educational Review, 5, 1-22.

Smith, D. K. (1954). Origin and development of departments of speech. In K. R. Wallace (Ed.), History of speech education in America: Background studies (pp. 447-470). New York: Appleton-Century.

Soltis, J. F. (1984). On the nature of educational research. Educational Researcher, 13, 5-10.

Sparks, C. C., \& Spirek, M. M. (1988). Individual differences in coping with stressful mass media: An activation-arousal view. Human Communication Research, 15, 195-216.

Sprague, J. (1992a). Critical perspectives on teacher empowerment. Communication Education, 41, 181-203.

Sprague, J. (1992b). Expanding the research agenda for instructional communication: Raising some unasked questions. Communication Education, 41, 1-25.

Sprague, J. (1993). Retrieving the research agenda for communication education: Asking the pedagogical questions that are "embarrassments to theory." Communication Education, 42, 106-122.

Sprague, J. (1994). Ontology, politics, and instructional communication research: Why we can't just "agree to disagree" about power. Communication Education, 43, 273-290.

Staton, A. Q. (1990). Communication and student socialization. Norwood, NJ: Ablex. 
Staton-Spicer, A. Q., \& Wulff, D. H. (1984). Research in communication and instruction: Categorization and synthesis. Communication Education, 33, 377-391.

Stewart, M. A., \& Ryan, E. B. (1982). Attitudes toward younger and older adult speakers: Effects of varying speech rates. Journal of Language and Social Psychology, 1, 91-109.

Thimm, C., Rademacher, U., \& Kruse, L. (1998). Age stereotypes and patronizing messages: Features of age-adapted speech in technical instructions to the elderly. Journal of Applied Communication Research, 26, 66-82.

Valkenburg, P. M., \& Janssen, S. C. (1999). What do children value in entertainment programs? A crosscultural investigation. Journal of Communication, 49, 3-21.

Waldeck, J. H., Kearney, P., \& Plax, T. (2001) Instructional and developmental communication theory and research in the 90s: Extending the agenda for the 21st century. In W. Gudykunst (Ed.), Communication yearbook 24 (pp. 207-230). Newbury Park, CA: Sage.

Weiss, A. J., \& Wilson, B. J. (1998). Children's cognitive and emotional responses to the portrayal of negative emotions in family-formatted situation comedies. Human Communication Research, 24, 584-609.

Williams, A., \& Nussbaum, J. F. (2001). Intergenerational communication across the life span. Mahwah, NJ: Erlbaum.

Wilson, B. J. (1987). Reducing children's emotional reactions to mass media through rehearsed explanation and exposure to a replica of a fear object, Human Communication Research, 14, 3-26.

Wilson, B. J. (Ed.). (2002). Special issue of the Journal of Communication, 52, 5-138.

Wilson, B. J., \& Cantor, J. (1985). Developmental differences in empathy with a television protagonist's fear. Journal of Experimental Child Psychology, 29, 284-299.

Wilson, B. J., Hoffner, C., \& Cantor, J. (1987). Children's perceptions of the effectiveness of techniques to reduce fear from mass media. Journal of Applied Developmental Psychology, 8, 39-52. 